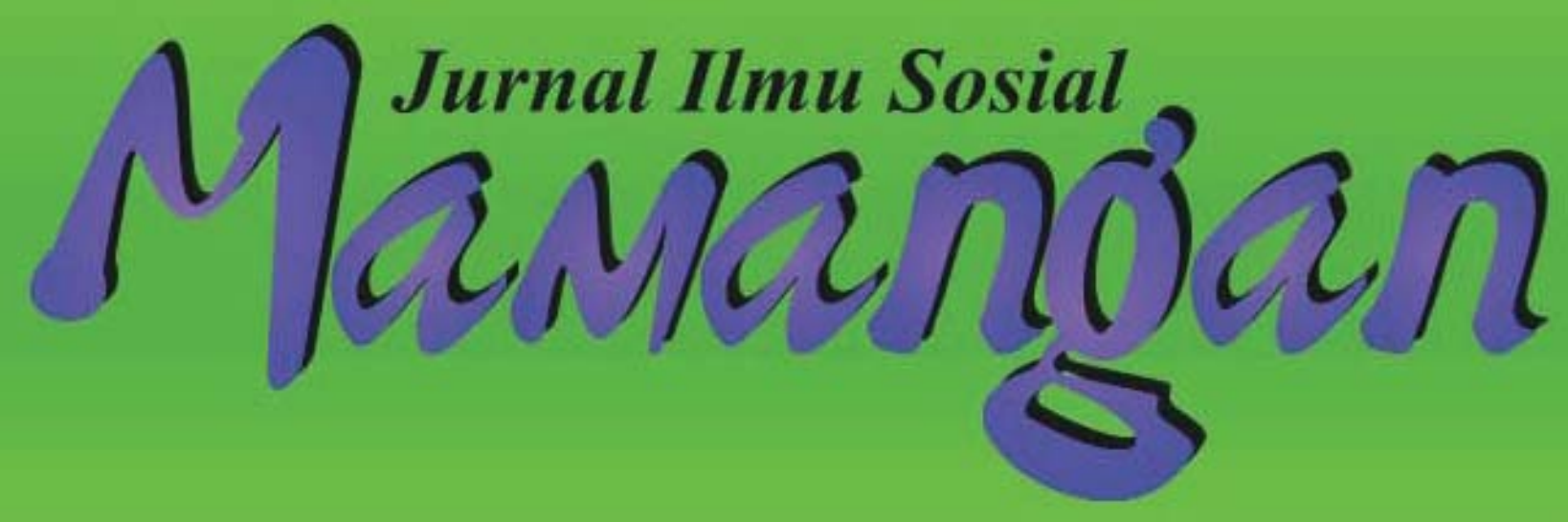

Beberapa Hipotesis Tentang Eksklusi Sosial di Indonesia Robert M.Z. Lawang

Dapatkah Indonesia Bebas Dari Kutukan Kolonial?

Refleksi Kritis Atas MP3EI

Noer Fauzi Rachman \& Dian Yanuardy

Rontoknya Dominasi Negara di Tambang Batu Bara Ombilin Sawahlunto

Zaiyardam Zubir \& Zulqayyim

Protes Korban Bencana; Studi Konflik Penanggulangan Bencana di Pasar Raya Padang

Firdaus

Peran Perempuan dalam Resolusi Konflik Rehabilitasi dan Rekonstruksi Pasar Raya Padang Ira Ariesta

Resolusi Konflik Berbasis Adat; Studi Resolusi Konflik Harta Pusaka Tinggi di Nagari Gantuang Ciri, Kab. Solok, Sumatera Barat

Yuhelna

Nelayan Vs Rentenir; Studi Ketergantungan Nelayan terhadap Rentenir pada Masyarakat Pesisir Delmira Syafrini 


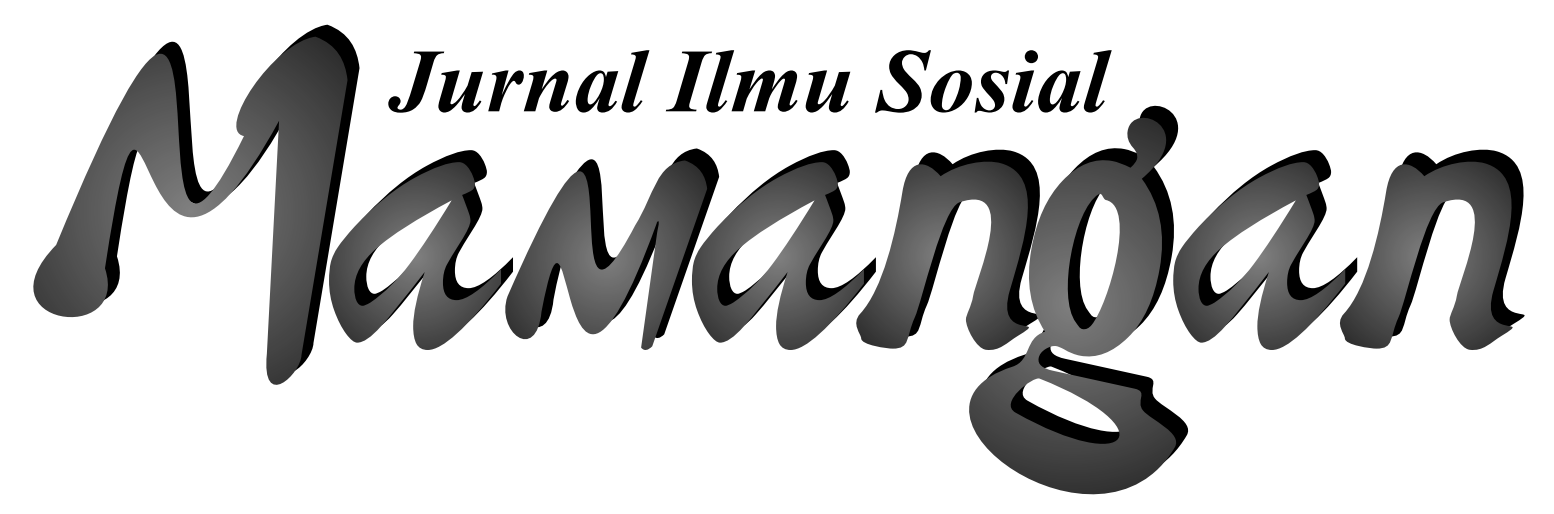




\section{Mitra Bestari}

Prof. Dr. Afrizal, MA. (FISIP, Unand Padang)

Prof. Dr. Badaruddin, M. Si. (FISIP, USU Medan)

Dr. A. Latief Wiyata, M. Si. (Universitas Jember, Jember)

Dr. Fikarwin Zuska, M. Si. (FISIP, USU Medan)

Nurus Shalihin, M. Si., Ph.D. (Fak. Ushuluddin IAIN Imam Bonjol Padang)

Dr. Semiarto A. Purwanto, M. Si. (FISIP, UI Jakarta)

Dr. Wahyu Wibowo, M. Si. (Universitas Nasional, Jakarta)

\section{Dewan Redaksi}

Dr. Zusmelia, M. Si.

Dr. Maihasni, M. Si.

Firdaus, S. Sos., M. Si.

\section{Pemimpin Redaksi/Editor}

Firdaus, S. Sos., M. Si.

\section{Anggota Redaksi}

Dian Kurnia Anggreta, S. Sos., M. Si.

Rinel Fitlayeni, S. Sos., MA.

Rio Tutri, M. Si

Sri Rahayu, M. Pd

Surya Prahara, SH,. MH.

Yuhelna, MA.

ISSN: 2301-8496

viii +81 halaman, $21 \times 29 \mathrm{~cm}$

\section{Alamat Redaksi:}

Laboratorium Program Studi Pendidikan Sosiologi, STKIP PGRI Sumbar Kampus STKIP PGRI, Jl. Gunung Pangilun, Padang, Sumatera Barat

Email: redaksimamangan@yahoo.com \& daus_gila@yahoo.com

\section{Penerbit:}

Laboratorium Program Studi Pendidikan Sosiologi, STKIP PGRI Sumbar

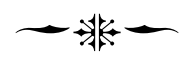




\section{PENGANTAR REDAKSI}

K onflik dalam masyarakat merupakan keniscayaan. Ia akan terus menjadi bagian dalam dinamika kemasyarakatan dan mengejawantah dalam berbagai bentuk yang secara garis bersar dikategorikan sebagai bentuk laten dan bentuk manifest. Pola dan bentuk konflik juga terus mengalami perkembangan sesuai dengan tingkat perkembangan masyarakat dimana konflik tersebut ada. Pola dan bentuk itu, mulai dari yang sederhana hingga yang paling 'canggih' dan bahkan disengaja ada untuk kepentingan tertentu oleh kelompok tertentu.

Meskipun para penganut fungsionalisme meganggap bahwa konflik dalam kehidupan sosial adalah abnormal (Johnson, 1994:161), namun konflik di lain kesempatan merupakan fakta sosial yang bisa fungsional bagi struktur tertentu selama ia dikelola dengan baik. Maka konflik kemudian di beberapa kesempatan juga dibutuhkan untuk kepentingan-kepentingan tertentu. Sehingga dengan demikian, adakalanya konflik mengikuti polanya sendiri dan adakalanya seirama dengan perkembangan masyarakat.

Menyadari bahwa perkembangan masyarakat terus melaju ke bentuk yang lebih kompleks, dan asumsi bahwa konflik juga akan kompleks sesuai dengan perkembangan kompleksitas masyarakat, Mamangan Edisi II yang ada di tangan pembaca ini mengambil konflik sebagai tema umum. Dalam edisi ini konflik dilihat oleh penulis dalam berbagai dimensi melalui berbagai pendekatan, baik secara teoritis maupun empiris melalui studi lapangan. Beberapa pakar di bisangnya telah menyumbang dalam dalam edisi kedua ini.

Tulisan pertama disumbangkan oleh Prof. Robert Lawang yang mendiskusikan konsep eksklusi sosial dalam konteks sosial, ekonomi dan politik. Tiga ranah ini menurut Lawang dikuasai arus utama (main stream) yang tidak mudah dimasuki oleh kelompok sosial tertentu dalam masyarakat paling bawah (underclass), sehingga mereka mengalami deprivasi. Selain itu, Lawang juga menyebut adanya perbedaan pandangan dan cara menjelaskan gejala sosial yang terkait eksklusi sosial. Meskipun konsep eksklusi sosial adalah konsep Barat, namun di Indonesia menurut Lawang, eksklusi sosial terjadi dalam berbagai struktur sosial masyarakat, baik di perkotaan maupun di pedesaan. 
Tulisan kedua disumbangkan oleh Noer Fauzi Rachman dan Dian Yanuardy yang mengupas secara kritis MP3EI. Dalam tulisannya, Fauzi dan Dian mempreteli skema MP3EI dan menyebutnya sebagai bagian dari upaya untuk memperdalam integrasi tanah air Indonesia ke dalam zona perdagangan bebas ASEAN dan Asia Timur. menurut mereka MP3EI pada pokoknya bertumpu pada upaya untuk melakukan reorganisasi ruang dalam rangka memperlancar interaksi dan aliran kapital, barang dan tenaga kerja untuk aktivitas produksi-konsumsi. Skema MP3EI dalam pola pemberian lisensi pada perusahaan untuk mengeksploitasi Sumber daya Alam menurutnya tidak jauh berbeda dengan kebijakan pemerintah kolonial Belanda sejak 1870, yang menempatkan Indonesia sebagai tempat produksi komoditas global.

Tulisan ketiga disumbangkan oleh Zayardam Zuber dan Zulqayim tentang rontoknya dominasi negara di Tambang Batubara Omblin, Sawahlunto. Zayardam dan Zulqayim dalam tulisannya mengemas sejarah beralihnya tambang di Kota Sawahlunto dari tangan perusahaan ke tangan rakyat yang selama puluhan tahun hanya menjadi penonton di arena tambang. Proses peralihan tersebut menurut Zayardan dan Zulqayim antara lain dilatari oleh penguasaan terhadap lahan di sekitar tambang yang dikuasi oleh dua kelompok, yaitu masyarakat adat dan pemerintah daerah. Selain itu, menurunnya aktivitas tambang PT. BA-UPO selaku BUMN yang kemudian menyerahkan pengurusan tambang kepada Pemda setempat juga menjadi bagian dari latar rontokya dominasi negara.

Tulisan keempat disumbangkan oleh Firdaus yang menguraikan protes korban bencana dalam proses rehabilitasi dan rekonstruksi di Pasar Raya Padang. Firdaus menyebutkan faktor penyebab munculnya protes adalah kebijakan pembangunan yang tidak partisipatif dan merugikan pedagang yang merupakan korban bencana. Kebijakan itu dibuat oleh pemerintah melalui mekanisme yang tidak sesuai dengan aturan yang ada. Protes yang dilakukan oleh korban bencana dilakukan dengan berbagai strategi, mulai dari strategi konfrontasi hingga negosiasi.

Tulisan kelima disumbangkan oleh Ira Ariesta yang mengulas peran perempuan dalam resolusi konflik Pasar Raya Padang. Ulasan Ira 'nyambung' dengan tulisan Firdaus sebelumnya. Jika Firdaus lebih menekankan pembahasan tentang penyebab dan strategi protes, maka Ira lebih menekankan pada resolusi konflik. Resolusi konflik yang dibahas Ira lebih fokus lagi pada peran perempuan. Menurut Ira, peran perempuan dalam proses resolusi konflik di Pasar Raya dilakukan oleh empat aktor utama, yaitu perempuan dari instansi pemerintah, perempuan aktivis LSM (PBHI Sumbar), perempuan aktivis mahasiswa dan perempuan pedagang. Keempat kelompok memainkan peran yang berbeda dalam resolusi konflik, mulai dari aksi massa hingga kegiatan advokasi terorganisir.

Tulisan keenam disumbangkan oleh Yuhelna yang membahas tentang mekanisme penyelesaian konflik harta pusaka tinggi secara adat di Minangkabau. Penyelesaian konflik harta pusaka tinggi di Minangkabau dilihat di nagari Gantuang Ciri. Resolusi konflik dilakukan pada 3 tingkatan. Tingkatan pertama resolusi konflik dilakukan di tingkat suku dengan melibatkan pangulu suku. Tingkat kedua resolusi konflik dilakukan pada tingkat yang lebih luas, yaitu pada institusi Tigo Niniak atau Ampek Niniak. Pada tingkat ini, resolusi konflik difasilitasi oleh niniak mamak masing-masing suku atau kaum yang berkonflik. Pada tingkat ketiga resolusi konflik dilakukan di lembaga adat Kerapatan Adat Nagari (KAN). Resolusi konflik pada tingkat ini difasilitasi oleh pengurus KAN yang merupakan perwakilan dari semua suku yang ada dalam nagari.

Tulisan terakhir, disumbangkan oleh Delmira Syafrini yang menganalisis ketergantungan nelayan dengan tengkulak di wilayah pesisir. Delmira melihat ketergantungan nelayan terhadap rentenir sebagai fenomena yang dilematis. Di satu sisi, nelayan mendapat kemudahan mengakses 
modal, di sisi lain nelayan dirugikan dengan suku bunga yang tinggi. Sementara, lembaga keuangan seperti Bank belum mampu menjadi katup penyelamat karena mekanisme rungguhan yang disyaratkan lembaga ini tidak terjangkau oleh nelayan. Di bagian akhir, Delmira menawarkan pemberdayaan sebagai solusi untuk memutus ketergantungan nelayan terhadap rentenir.

Demikianlah tulisan pada edisi ini, dan kepada para penyumbang tulisan pada edisi ini redaksi mengucapkan terima kasih atas karya intelektual dan buah pemikiran mereka, dan kepada para pembaca, redaksi mengucapkan selamat membaca. 



\section{DAFTAR ISI}

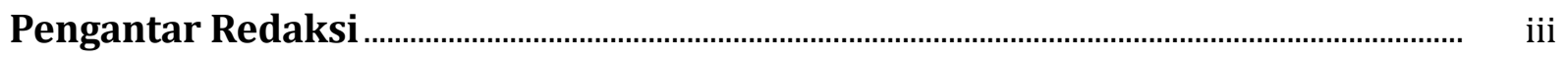

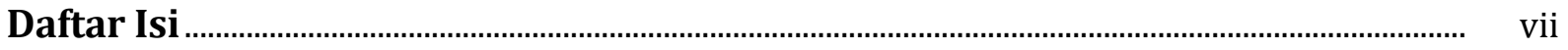

Beberapa Hipotesis Tentang Eksklusi Sosial di Indonesia

Robert M.Z. Lawang

Dapatkah Indonesia Bebas Dari Kutukan Kolonial?

Refleksi Kritis Atas MP3EI

Noer Fauzi Rachman \& Dian Yanuardy

Rontoknya Dominasi Negara di Tambang Batu Bara Ombilin Sawahlunto

Zaiyardam Zubir \& Zulqayyim

Protes Korban Bencana; Studi Konflik Penanggulangan Bencana di

Pasar Raya Padang

Firdaus

Peran Perempuan dalam Resolusi Konflik Rehabilitasi dan Rekonstruksi

Pasar Raya Padang

Ira Ariesta

Resolusi Konflik Berbasis Adat; Studi Resolusi Konflik Harta Pusaka Tinggi di Nagari Gantuang Ciri, Kab. Solok, Sumatera Barat

Yuhelna

Nelayan Vs Rentenir; Studi Ketergantungan Nelayan terhadap Rentenir pada Masyarakat Pesisir

Delmira Syafrini .

Profil Penulis. 



\title{
NELAYAN VS RENTENIR Studi Ketergantungan Nelayan terhadap Rentenir pada Masyarakat Pesisir
}

\author{
Delmira Syafrini \\ (Dosen Pendidikan Sosiologi-Antropologi, Fakultas Ilmu Sosial, Universitas Negeri Padang) \\ 一非-
}

\begin{abstract}
Abtract
The dept and moneylender phenomenon is a problem on fishing communities in Indonesia today. Moneylenders and fishing has become an integral part. Most of fishermen in Indonesia trapped in the vortex of debt to moneylenders as vicious circle that can't be disconnected. Once they are dealing with a loan shark then lifetime will continue to be pursued and wrapped debt, due to the fact that the interest charged is very high even up to 20-40 percent. So that the nominal amount of debt continues to increase and even not in accordance with the amount of income they get. This paper outlines the fishermen being stuck rentenis and efforts should be made to break the chain of being stuck to the loan shark fishing in accordance with local knowledge.
\end{abstract}

Kata kunci: Nelayan, Rentenir, Pemberdayaan

\section{Pendahuluan}

Masalah ekonomi adalah masalah yang sangat penting dalam kehidupan manusia, ia ada beserta terciptanya nenek moyang manusia di muka bumi. Sistem perekonomian telah dikenal semenjak zaman primitif, pada zaman manusia hidup pada tatanan yang sederhana, dengan hidup nomaden dengan mata pencarian berburu dan meramu (food hunting and ghatering) dan juga pada masa hidup menetap (food producing). Pada masa ini uang belum dikenal dalam kehidupan tapi adanya sistem barter (barang ditukar dengan barang) menandai bahwa manusia untuk bertahan hidup sangat membutuhkan manusia lain. Walaupun mereka hidup dalam pola sederhana tapi sistem pembagian kerja yang juga bagian dari sistem perekonomian telah mereka praktekkan. Jadi bisa dikatakan kegiatan perekonomian ada sepanjang sejarah hidup manusia, masa lalu, hari ini, dan masa yang akan datang yang diwujudkan dalam bentuk lembaga perekonomian dalam rangka memenuhi kebutuhan hidup manusia

Salah satu lembaga perekonomian yang sangat penting adalah pasar dimana ia merupakan penggerak utama dinamika kehidupan ekonomi karena di sinilah kegiatan ekonomi bisa dilaksanakan. Pasar bukan hanya 
diartikan pada makna yang sempit yaitu tempat pertemuan antara penjual dan pembeli tapi lebih merujuk pada adanya proses tawar menawar di dalamnya dalam rangka pertukaran barang, uang dan jasa yang melibatkan banyak aktor. Menurut pendekatan jaringan sosial melihat pasar sebagai suatu struktur hubungan antara beberapa aktor pasar seperti perusahaan, distributor, pemasok, pesaing dan pembeli yang kesemua aktor membentuk suatu kompleksitas jaringan hubungan yang melibatkan modal budaya (cultural capital) dan modal sosial (sosial capital) (Damsar, 2002: 89).

Pasar tidak akan bergerak tanpa adanya peran dari pada aktor yang terlibat di dalamnya, sementara untuk basis perkembangan dan mekanisme pasar uang memiliki peranan yang juga tidak kalah penting. Jadi bicara masalah pasar, modal, aktor dan tawar menawar maka tidak akan lepas dari masalah uang, karena apapun kegiatan ekonomi pasti akan merujuk pada keuntungan (provit) yang dalam hal ini tercipta dalam wujud uang. Dalam masyarakat modern dewasa ini uang adalah faktor utama yang dianggap sangat penting, hidup bahagia karena uang dan juga sengsara karena uang. Maka tidak jarang permasalan sosial muncul hari ini karena masalah ada atau tidaknya uang. Salah satu masalah yang muncul dari persoalan diatas adalah jebakan hutang oleh rentenir dalam kehidupan masyarakat kelas bawah.

Fenomena hutang dan rentenir juga merebak terjadi pada komunitas nelayan di Indonesia saat ini. Sebagian besar nelayan di Indonesia digambarkan sebagai komunitas yang hidup subsistem dengan pendapatan yang tidak hanya kecil, tapi juga tidak menentu (Yustika, 2003: 64). Hidup di tengah-tengah kekayaan laut yang melimpah tidak sinergis dengan perekonomian nelayan yang cenderung berkekurangan, karena penghasilan mereka sangat ditentukan oleh faktor alam dan cuaca. Ada masanya mereka mendapatkan penghasilan yang cukup dari hasil melaut ketika cuaca baik, tapi ketika cuaca buruk maka di sinilah masa panceklik bagi nelayan, karena pada masa ini mereka tidak mendapatkan apa-apa dari hasil melaut. Pada saat seperti inilah nelayan butuh pertolongan untuk menyelamatkan kehidupan keluarga, tidak ada jalan lain selain berhutang dan rentenir pun menjadi jalan cepat untuk memberikan solusi. Tulisan ini akan membahas fenomena nelayan di antara pusaran jebakan rintenir, yang menurut mereka adalah solusi tapi justru bisa menjadi jebakan mati bagi kehidupan nelayan itu sendiri, serta alternatif solusi/ pemberdayaan yang dilakukan untuk memutus mata rantai rintenir melalui budaya lokal.

\section{Tinjauan Pustaka}

Konsep pemberdayaan merupakan salah satu alternatif pemecahan berbagai permasalahn yang terjadi dalam masyarakat dewasa ini. Konsep ini mencakup nilai-nilai sosial yang mencerminkan paradigma baru pembangunan yang bersifat "people-centered, participatory, empowering, and sustainable" (Chambers, 1995). Konsep ini lebih luas dari hanya semata-mata memenuhi kebutuhan dasar atau menyediakan mekanisme untuk mencegah proses pemiskinan lebih lanjut, yang pemikirannya belakangan ini banyak dikembangkan sebagai upaya mencari alternatif terhadap konsep-konsep pertumbuhan di masa yang lalu. Konsep ini berkembang dari upaya banyak ahli dan praktisi untuk mencari apa yang antara lain oleh Friedmann (1992) disebut alternative development, yang menghendaki inclusive democracy, appropriate economic growth, gender equality and intergenerational equity.

Secara konseptual, pemberdayaan masyarakat adalah upaya untuk meningkatkan harkat dan martabat lapisan masyarakat yang dalam kondisi sekarang tidak mampu untuk melepaskan diri dari perangkap kemiskinan dan keterbelakangan. Dengan kata lain memberdayakan adalah memampukan dan 
memandirikan masyarakat. Dalam konsep pemberdayaan, manusia adalah subyek dari dirinya sendiri. Proses pemberdayaan yang menekankan pada proses memberikan kemampuan kepada masyarakat agar menjadi berdaya, mendorong atau memotivasi individu agar mempunyai kemampuan atau keberdayaan untuk menentukan pilihan hidupnya.

Edi Suharto (2006) juga mengungkapkan bahwa pada prinsipnya pemberdayaan masyarakat juga diperlukan dalam pembangunan nasional di suatu negara bangsa (nation state). Dalam hal ini pemberdayaan masyarakat tersebut memiliki tiga tugas utama yakni pertumbuhan ekonomi (economic growth) perawatan masyarakat (community care) dan pengembangan manusia (human development). Fungsi pertumbuhan ekonomi mengarah pada usaha untuk memperoleh pendapatan finansial untuk membiayai pembangunan. Fungsi perawatan menyangkut pelayanan dan perlindungan terhadap keselamatan dan kelangsungan kehidupan warga negara (seperti pelayanan kesehatan dan pendidikan), sementara fungsi pengembangan manusia mengarah pada peningkatan kompetensi sumber daya manusia dalam rangka penyediaan tenaga kerja berkualitas yang pada dasarnya juga mendukung jalannya pembangunan. Dalam rangka mencapai pembangunan nasional yang optimal maka ketiga aspek di atas harus dijalankan secara seimbang karena fungsi perawatan dan pengembangan manusia inilah yang merupakan substansi pembangunan sosial yang menopang pembangunan ekonomi.

Berbagai studi memberi pesan yang sangat jelas bahwa negara yang kuat dan sejahtera adalah negara yang memperhatikan pertumbuhan ekonomi dan sekaligus memiliki komitmen menjalankan pembangunan sosial. Laporan UNDP, Human Development Report secara konsisten menunjukkan bahwa pembangunan sosial mendorong pertumbuhan ekonomi dan pertumbuhan ekonomi yang tidak memperhatikan pembangunan sosial tidak akan bertahan lama.

Banyak konsep pembangunan di negara berkembang menemui kegagalan karena memisahkan pembangunan sosial dengan pembangunan ekonomi. Sektor-sektor yang dikelompokkan dalam bidang sosial seperti pendidikan dan kesehatan menjadi terabaikan dan terkalahkan oleh sektor ekonomi. Padahal terbukti bahwa pembangunan negara-negara industri baru berhasil karena penekanan yang diberikan pada bidang pendidikana dan pengembangan sumber daya manusia. Bahkan Gary Becker pemenang nobel tahun 1992 mempelopori apa yang disebutnya sebagai human capital (modal manusia), dimana investasi modal manusia berupa pendidikan, pelatihan, dan pelayanan kesehatan ini dari berbagai penelitian ternyata menghasilkan sesuatu yang tidak kalah penting dari investasi modal fisik (Kartasasmita, 1996)

Modal manusia inilah yang saat ini dibutuhkan untuk memutus mata rantai eksploitasi terhadap nelayan di Indonesia, karena untuk pengolahan sumber daya alam yang melimpah juga harus ditunjang dengan sumber daya manusia yang berkualitas. Nelayan Indonesia sudah selayaknya diberikan pengetahuan bahwa hasil laut yang melimpah bisa dikelola secara optimal untuk kesejahteraan mereka.

\section{Nelayan Vs Rentenir; antara Uang, Modal dan Hutang}

Ciri utama ekonomi pasar adalah penggunaan uang sebagai sarana transaksi dan orientasi tindakan ke arah profit ketimbang pelaku ekonomi. Uang adalah modal utama dalam mengembangkan akses perekonomian, namun fenomenanya penyebaran uang dalam masyarakat cenderung tidak merata, dalam era kapitalisme dewasa ini yang ditandai dengan ekspansi pasar sudah menjadi konsekwensi 
bahwa masyarakat akan tetap dibagi menjadi beberapa kelompok yang menciptakan gape antara kaum pemilik modal dan buruh, antara si kaya dan si miskin. Bahkan beberapa data yang ada menggambarkan kenyataan bahwa saat ini praktek ekonomi neo-liberal semakin mempertinggi kesenjangan hidup manusia karena hanya ada seperlima penduduk bumi yang menikmati 80 persen dari pendapatan dunia (Swastika: 226). Ini artinya ekspansi pasar bagaimanapun juga akan tetap memarginalkan kaum miskin dalam akses ekonomi karena permasalahan kepemilikan modal.

Dalam mengatasi masalah kepemilikan modal ini pemerintah telah memberikan satu solusi dengan memberikan peluang untuk peminjaman modal dengan mendirikan lembagalembaga finansial formal seperti bank milik pemerintah, koperasi simpan pinjam yang biasanya dikelola langsung oleh negara ataupun pasar. Pada mulanya lembaga ini menjadi solusi yang dimanfaatkan rakyat, untuk memperkuat perekonomiannya karena selain mekanismenya jelas, bunga yang dibebankan juga relatif kecil. Tapi pada perkembangan selanjutnya, seiring berkembangnya lembaga ini, lembaga finansial informal juga mengambil posisi yang signifikan dalam memberikan pinjaman modal kepada rakyat kelas bawah, lembaga ini berkembang begitu cepat dan mendapatkan posisi sendiri di hati "rakyat kecil". Rentenir misalnya, kehadirannya saat ini justru lebih dicari dan dibutuhkan rakyat kecil daripada bank yang jelas-jelas lebih bersifat legal dengan bunga yang relatif kecil, sehingga rentenir yang menawarkan bunga yang cenderung sangat tinggi seolah tumbuh menjadi "pahlawan" bagi kehidupan rakyat kecil yang membebaskan mereka dari pasungan kesulitan hidup walaupun sesungguhnya mereka sangat menyadari bahwa berhubungan dengan rentenir semakin membuat mereka terkungkung dalam pasungan yang lebih mengikat bahkan mematikan.

Pertanyaan menarik bagi kita tentunya mengapa nelayan lebih memilih rentenir untuk mendapatkan sejumlah bantuan, ketimbang bank yang jelas lebih legal dengan bunga yang ringan? Jawabannya bagi mereka sangat sederhana, bantuan memang banyak yang menawarkan, akan tetapi syarat untuk mendapatkan pinjaman yang sangat sulit mereka penuhi. Hal ini terungkap dari penyataan pak Nyoman, salah satu nelayan Purus berikut ini:
....Yo, apo nan kadiaroan jo kondisi bantuak ko lai, rasaki kami ndak jaleh pemasukan saketek, pengeluaran banyak. Sahinggo kok nak sakola anak utang nan tumbuah. Maminjam ka bank, syarat banyak.rancaklah nan jaleh se lai, tengkulak lai (Dalam bahasa daerah Minangkabau) (Wawancara tanggal 12 Mei 2013)

\section{Terjemahan:}

“...Apa lagi yang bisa kita harapkan dari situasi seperti ini, reski kami tidak jelas, pengeluaran banyak penghasilan sedikit. Agar anak tetap sekolah tentu harus berhutang. Hutang ke bank syarat terlalu banyak, jadi sebaiknya meminjam ketempat yang lebih jelas saja seperti tengkulak".

Hal serupa juga terungkap dari Nasrul bahwa:

“...Kok nelayan ko rasaki nyo rasaki rimau. Istilahnyo pambali ameh dapek pambali bareh ndak dapek do. Kalau tibo musimnyo, bapitih banyak loh awak ma, kok indak rokok sabtang se ndak dapek do. Jadi katiko musim ndak ado baa caro iduik lai tapaso minjam jo tangkulak karano urusan labiah capek"(Dalam bahasa daerah Minangkabau) (Wawancara tanggal 14 Mei 2013)

\section{Terjemahan:}

“...Nelayan ini rezkinya sama dengan rezki harimau, istilahnya untuk membeli emas ias untuk membeli beras tak ada, kalau tiba musimnya banyak kami dapat uang, tapi kalau tidak untuk membeli rokok saja susah. Jadi ketika susah harus meminjam ke tengkulak untuk melajutkan hidup karena lebih cepat berurusan ke mereka"

Dari pernyataan informan di atas terlihat bahwa nelayan lebih memilih tengkulak dari pada lembaga formal. Hal ini tentu merupakan alasan yang logis karena meminjam ke lembaga formal seperti bank tentunya harus disertai dengan sederet syarat sebagai jaminan hutang saat mengajukan kredit perbankan, seperti foto kopi KTP, Kartu Keluarga, Surat Nikah bahkan 
sampai pada jaminan surat tanah, rumah atau sekedar surat kepemilikan kendaraan bermotor dan sejumlah syarat lainnya yang tentunya memberatkan nelayan. Belum lagi pemenuhan permohonan hutang yang baru bisa dipenuhi dalam waktu yang relatif lama. Sementara rentenir jelas menawarkan pinjaman dengan syarat yang jauh lebih ringan dan bisa dipenuhi dalam waktu yang relatif cepat. Hal inilah yang, membuat nelayan lebih memilih rentenir sebagai tempat melepas sesak sesaat, tanpa berfikir dampak panjang yang datang menyertainya.

\section{Nelayan dalam Jebakan Rentenir}

Rentenir dan nelayan seolah telah menjadi satu bagian yang tidak terpisahkan. Sebagian besar nelayan Indonesia terjebak dalam pusaran hutang kepada rentenir seperti lingkaran setan yang tidak bisa diputus. Ironis memang, nelayan yang tidak hanya identik dengan kemiskinan tapi juga terjebak dalam belenggu mematikan. Sekali mereka berurusan dengan rentenir maka seumur hidup akan terus dikejar dan dibelit hutang, karena faktanya bunga yang dikenakan sangat tinggi bahkan sapai 20-40 persen. Sehingga jumlah nominal hutang terus meningkat bahkan tidak sesuai dengan jumlah penghasilan yang mereka dapatkan. Hal ini tentu menjadi sangat dilematis, karena mengingat Indonesia adalah negara maritim yang kaya akan hasil laut, tapi tidak sebanding dengan kehidupan nelayan yang justru terjerat dalam kemiskinan yang tidak terlepas dari kemiskinan dan hutang. Bahkan data BPS mencatat bahwa data nelayan miskin indonesia pada tahun 2013 mencapai 7,87 juta orang atau sekitar 25,14 persen dari total penduduk miskin nasional yang mencapai 31,02 juta orang dari keseluruhan penduduk Indonesia., yang mayoritas dari mereka terjerat hutang terhadap rentenir.

Faktor Penyebab Jeratan hutang nelayan terhadap rentenir ini tidak terlepas dari berbagai faktor, salah satunya adalah pengaruh akses modal. Sebagaimana kita ketahui, sebagian nelayan Indonesia saat ini masih tergolong nelayan tradisional yang memiliki alat tangkap yang terbatas, dengan keahlian yang juga terbatas sehingga kegiatan melaut sebagai satu-satunya solusi untuk bertahan hidup. Sehingga untuk mendapatkan modal untuk membeli fasilitas melaut, nelayan terpaksa berhutang kepada apa yang mereka sebut sebagai juragan (rentenir dalam bahasa halus). Para juragan yang memiliki kecerdasan untuk menangkap peluang ini, memanfaatkan kelemahan nelayan untuk mengeruk keuntungan sebanyak-banyaknya dengan menjalankan sistem ijon.

Sistem ijon dijalankan dengan memberikan modal kepada para nelayan untuk membeli kapal dan perbaikan alat dan sarana untuk melaut. Namun ini dilakukan bukan cuma-cuma tentunya, tapi nelayan harus menanggung resiko seumur hidup, karena untuk membayar semua itu nelayan diwajibkan untuk menjual hasil tangkapannya kepada juragan yang bersangkutan dengan potongan harga seumur hidup. Bahkan hasil tangkapan dibeli dengan harga yang sangat murah, bahkan uang hasil penjualan juga diberikan pada juragan untuk membayar hutang beserta bunga yang sangat tinggi. Ini artinya hasil yang didapatkan nelayan tidak sesuai dengan jerih payah yang mereka lakukan. Hasilnya mereka akan terikat dengan hutang secara permanen, walaupun hasil tangkapan melimpah akan tetapi akan tetap dijual dengan harga yang murah. Seperti terungkap dari Bapak Poan berikut :

“...barutang ka tangkulak ko, samo jo gali lubang tutup lobang. Barutang tapi bayia labiah gadang. Kok tibo musim ikan hasil banyak samo jo indak, wak harus manjua ka juragan tu, nyo bali jo harago murah, kok dipasa Rp.10.000 sakilo, nyo bali Rp.7000 sakilo. Alah tu hasil labiah panjualan bayia lu ka bungo utang. "(Dalam bahasa daerah Minangkabau) (Wawancara tanggal 15 Mei 2013)

\section{Terjemahan :}

“...berhutang ke tengkulak, sama dengan gali lobang tutup lobang. Berhutang tapi membayar dengan harga yang lebih tinggi. Kalau sampai waktu musim ikan percuma, karena kami harus menjual dengan harga murah, jika harga pasar Rp.10.000/ kg, rentenir Rp. 7000/ kg.. Bukan 
hanya itu hasil penjualan juga harus diserahkan kepada mereka"

Hal ini diperkuat oleh pernyataan Buk Yus Katuak istri dari bapak Katuak, sebagai berikut :

\begin{abstract}
“...Iduik malauik ko payah ndak dari dulu sampai kini samo senyo, kami lah taparangkap bautang ka tangkulak. Sabananyo samo jo gantuang diri, wak nyo cakiak, pitih dapek ka modal, tapi hasil lauik nyo kuasai. Sahinggo kalaupun hasil laut banyak tapi lah abih bayia utang se (Dalam bahasa daerah Minangkabau) (Wawancara 16 Mei 20013).
\end{abstract}

\section{Terjemahan:}

“...Hidup sebagai nelayan inu memang sulit, kami terperangkap hutang ke tengkulak. Sebenarnya sama dengan gantung diri, siste mencekik kita. Uang didapat untuk modal, tapi hasil laut mereka kuasai. Sehingga meskipun hasil laut banyak tapi sudah habis untuk membayar hutang"

Dari pernyataan informan diatas dapat dilihat bahwa sistem yang diterapkan oleh rentenir untuk menjebak nelayan dengan cara, meminjamkan sejumlah modal untuk biaya melaut, tapi dengan kesepakatan bahwa hasil laut harus dijual kepada rentenir dengan kontrak harga yang lebih redah dengan harga pasar, Hal ini tentu merugikan nelayan secara sepihak. Belum lagi bunga hutang yang harus dibayar ketika musim ikan, sehingga disaat seharusnya mereka bisa menikmati hasil pekerjaan mereka, justru mereka terjebak dalam pusaran hutang yag tidak berujung. Jika kondisinya seperti ini lalu kapankah nelayan keluar dari jebakan hutang dan kemiskinan? Agaknya pemerintah perlu memberikan perhatian khusus pada masalah ini.

\section{Pemberdayaan; Memutus Eksploitasi Rentenir pada Masyarakat Pesisir}

Tidak ada manusia yang tidak ingin terlepas dari jerat hutang dalam kehidupannya, begitu juga dengan nelayan. Rentenir yang ada di sekeliling mereka merupakan ancaman bagi kehidupan dan masa depan nelayan, tapi apa yang harus mereka lakukan jika jeratan itu semakin kuat sementara jalan terang untuk keluar tidak kunjung ditemukan? Walaupun sebenarnya rentenir pada dasarnya masih memiliki sisi positif dalam kehidupan masyarakat, seperti penelitian yang pernah dilakukan oleh Heru Nugroho di Bantul, ditemukan bahwa rentenir sebenarnya telah menjadi agen perkembangan dalam kehidupan masyarakat Bantul, karena kredit yang ditawarkan rentenir memberikan sumbangan yang cukup berarti bagi perkembangan aktivitas ekonomi penduduk lokal di bidang perdagangan (Nugroho, 2001).

Terlepas dari semua ini, memiliki manfaat atau tidak tetap saja praktek rentenir bukan sesuatu yang harus dilegalkan. Rentenir harus tetap dimusnahkan, meskipun kita menyadari bahwa untuk memutus mata rantai ini tentu bukan perkara yang mudah, tapi tetap saja ia akan tetap jadi permasalahan besar bagi kehidupan nelayan jika masalah ini tidak segera diatasi. Dan untuk pekerjaan besar ini tentunya diperlukan kerjasama yang kuat dari berbagai pihak, baik nelayan itu sendiri ataupun pemerintah yang memiliki peran untuk menjembati kesejahteraan rakyat. Program pemberdayaan perlu dilakukan di tingkatan nelayan, karena belenggu ini seharusnya tidak terjadi, jika nelayan memiliki kecerdasan yang cukup untuk memanfaatkan setiap peluang ekonomi untuk melepaskan diri dari jeratan kemiskinan.

Program pemberdayaan sebenarnya pernah dilakukan berupa PEMP (Program Pemberdayaan Masyarakat Pesisir) yang dikelola langsung oleh koperasi, tapi tetap hanya dijadikan sebagai slogan yang menguntungkan kelompok yang berkepentingan tanpa mencapai sasaran pada kebutuhan nelayan. Ketika program pemberdayaan telah dilakukan, tapi ternyata tak juga menjadi solusi yang diharapkan, maka siapa dan apa yang salah dalam hal ini? Maka sistem dan mekanisme pemberdayaan itu sendiri yang harus ditata kembali, karena selama ini pengelolaan PEMP selalu diserahkan kepada pihak luar sehingga peluang untuk penyalahgunaan program cenderung terjadi. 
Seharusnya kita kembali lagi pada hakekat pemberdayaan dan pembangunan itu sendiri, bahwa dalam pemberdayaan sudah seharusnya rakyat yang akan diberdayakan diikutsertakan dalam proses pemberdayaan tersebut agar hasil yang didapatkan tepat sasaran.

Kita belajar dari kesuksesan Provinsi Bali dalam pemberdayaan masyarakat dengan mengaktifkan program LPD (lembaga pengkreditan daerah) dimana didirikan program ekonomi simpan pinjam berbasis mikro yang langsung disesuaikan dengan budaya setempat, program ini berjalan dengan baik karena diiringi dengan kesadaran masyarakat dan didukung pula oleh kuatnya institusi adat. Ini artinya jika pemberdayaan seperti program PEMP ini dilakukan, nelayan pun semestinya harus dilibatkan, karena itu akan lebih efektif pengelolaannya. Bukan hanya sampai disana tapi program tersebut disesuaikan dengan adat istiadat dan budaya masyarakat setempat, serta harus adanya reward dan punishment yang mereka dapatkan sebagai implikasi program ini, seperti ungkapan George C Homans dalam teori pertukaran prilaku bahwa semakin tinggi nilai dan manfaat suatu tindakan maka kian senang seseorang melakukan tindakan itu (Poloma, 2000). Ini artinya ketika ada manfaat yang didapatkan dari program pemberdayaan ini, maka nelayan akan cenderung terlibat di dalamnya, dengan ikut melakukan aktifitas simpan-pinjam untuk menjalankan program. Jika nelayan telah terbiasa dan merasakan profit yang didapatkan maka rentenir secara lambat laun akan dilupakan, sehingga mata rantainya akan lapuk dan terputus secara perlahan. Jadi menghilangkan rintenir bukanlah sebuah kemustahilan, tapi sesuatu yang harus diupayakan, sehingga kesejahteraan nelayan Indonesia akan sesuai dengan limpahan kekayaan Indonesia sebagai negara maritim, sehingga semboyan dalam lagu 'Nenek Moyangku Seorang Pelaut" menjadi identitas dan kebanggaan generasi Indonesia.

\section{Penutup}

Rentenir yang ada di sekeliling nelayan merupakan ancaman bagi kehidupan dan masa depan mereka, tapi apa yang harus mereka lakukan jika jeratan itu semakin kuat sementara jalan terang untuk keluar tidak kunjung ditemukan? Walaupun sebenarnya rentenir pada dasarnya masih memiliki sisi positif dalam kehidupan masyarakat, tetap saja praktek rentenir bukan sesuatu yang harus dilegalkan. Rentenir harus tetap dimusnahkan, meskipun kita menyadari bahwa untuk memutus mata rantai ini tentu bukan perkara yang mudah, tapi tetap saja ia akan tetap jadi permasalahan besar bagi kehidupan nelayan jika masalah ini tidak segera diatasi.

Sudah saatnya untuk memutus mata rantai ini nelayan sendiri yang harus dilibatkan, dengan mendirikan program ekonomi simpan pinjam berbasis mikro yang langsung disesuaikan dengan budaya setempat, program tersebut disesuaikan dengan adat istiadat dan budaya masyarakat, perberdayaan yang berbasis kearifan lokal. Jika nelayan telah terbiasa dan merasakan profit yang didapatkan maka rentenir secara lambat laun akan dilupakan, sehingga mata rantainya akan lapuk dan terputus secara perlahan. Jadi menghilangkan rintenir bukanlah sebuah kemustahilan, tapi sesuatu yang harus diupayakan.

\section{Daftar Pustaka}

Damsar, 2002. Sosiologi Ekonomi. Jakarta: PT. RajaGrafindo Persada.

Erani, Ahmad Yustika, 2003. Negara Vs Kaum Miskin, Jakarta: Pustaka Pelajar

Kartasasmita, Ginanjar, 1996. Pembangunan Untuk Rakyat. Jakarta: Cides

Nugroho, Heru, 2001. Negara, Pasar dan Keadilan Sosial, Yogyakarta: Pustaka Pelajar. 
Poloma, Margaret, 2000. Sosiologi Kontemporer, Swastika, Alia, 2006. Komodifikasi Perempuan: Jakarta: CV. Rajawali Pers.

Tapak Ekonomi Neo-Liberal (Globalisasi dan

Soeharto, Edi, 2006. Membangun Masyarakat Neo Liberalism)., Yogyakarta: FISIP UGM. Memberdayakan Rakyat. Bandung: PT. Refika Aditama. 
